\title{
農村と都市の共生は可能か
}

\section{～定住地域圈を考える Part.1〜}

日 時：1998年11月20日(金) $13: 00 \sim 17: 30$

場 所：日本学術会議 講堂

東京都港区六本木 $7-22-34$

（地下鉄千代田線乃木坂駅下車）

プログラム：

開会挨拶 富田 正彦（日本学術会議会員・農村 計画学研連委員長・宇都宮大学教授)

$$
\cdots 13: 00 \sim 13: 10
$$

\section{I．報告：農村と都市の関係の新展開}

1. 相互刺激による価値の創造 $\cdots 13: 10 １ 3: 45$ 宮口 侗廸 (早稲田大学教授〈地理学〉)

2. 農村の新展開から都市との共生を考える

$\cdots 13: 45 \sim 14: 20$

長谷山 俊郎 (農業研究センター室長

〈農村生活科学〉)

3. 農村地域政策の課題一中小都市と農村の結 合

$\cdots 14: 20 \sim 14: 55$

祖田 修（日本学術会議会員・京都大大 学院教授〈農業経済学〉)

4.都市側から見る農村との共生

$\cdots 14: 55 \sim 15: 30$

清水 浩志郎（秋田大教授〈都市計画学〉）

$\begin{array}{ll}\text { 質疑応答 } & \cdots 15: 30 \sim 15: 40 \\ \text { 休憩 } & \cdots 15: 40 \sim 15: 50\end{array}$

II. 報告を受けての討論：農村と都市の共生は可 能か

$\cdots 15: 50 \sim 17: 20$

司会：武内 和彦 (農学研連委員. 東京大大 学院教授〈緑地環境学〉)

パネラー：藍沢 宏 (東京工大大学院教授〈建築 学〉)

：石田 憲治（農業工学研究所室長〈農 業土木学〉)

生源寺 真一（東京大大学院教授〈農 業経済学〉)

閉会挨拶 佐藤 洋平（農村計画学研連地域計画 専門委員会委員長・東京大大学院教授) $\cdots 17: 20 \sim 17: 30$
主催：日本学術会議農村計画学研究連絡委員会, 地域計画専門委員会, 日本学術会議社会環 境工学研究連絡委員会, 都市地域計画専門 委員会, 農村計画学会

共催: 日本都市計画学会, 農業土木学会, 土木学 会, 日本農業経済学会, 日本造園学会, 日 本建築学会, 日本地理学会, 総合農学会, 日本林学科, 森林計画学会, 日本農村生活 学会

協賛：全国農業土木技術連合，全国土地改良事業 団体連合会

農村計画学会は，昨年秋，日本学術会議農村計 画学研究連絡委員会, 地域計画専門委員会, 同社 会環境工学研究連絡委員会, 都市地域計画専門委 員会と共同主催により，下記のような内容に基づ いてシンポジゥムを開催した。同シンポは会員始 め多くの参加を得て成功裏に終わった。ここに当 日ご報告いただいた先生方の論文を揭載し，あら ためて会員諸兄にご報告する。

主旨：農村計画学会はこれまで学術会議をはじめ, 他学会と合同して都市，農村地域における広域的 レベルの課題，あり方などについて検討を進めて きた。定住地域圈の考え方をさらに具体的にする ためには，総合的な視点を踏まえ，新しい局面に 対応してその展開を考えなければならない。本学 会では既に同様の課題（定住地域圈）についてシ ンポジゥムを重ねてきた（本誌Vol.14，15．№. 4 参照)。今回, 「農村と都市の共生は可能か定住地域圈を考えるパート $1 」$ と題しシンポジウ 么を企画し, 自然地理学, 農村生活学, 農業経済 学, 地域計画学などの分野から主題の報告を頂き 議論することとした。変貌する農村社会, 都市と 同質化する農村生活, 経営体の変化・農法の変化 と農村地域, 都市と農村の交流などの背景, 具体 的事例を通して農村と都市の共生について議論を 深めていく。 